\title{
A Bibliometric Analysis of the Most Cited 50 Articles on Ankle Arthroscopy
}

\author{
Ayak Bileği Artroskopisi Konusunda En Çok Atıf alan 50 \\ Makalenin Bibliyometrik Analizi
}

\section{Özgün Araştırma Research Article}

Received/Geliș: 23.10.2019 Accepted/Kabul: 04.11.2019 Published Online: 31.08 .2020

Tolgahan Kuru Canakkale Onsekiz Mart Üniversitesi Tıp Fakültesi, Ortopedi ve Travmatoloji Ana Bilim Dalı, Çanakkale - Türkiye mdtolgahankuru@gmail.com ORCID: 0000-0003-1245-6390

H.A. Olçar 0000-0002-3097-3677 Yozgat Şehir Hastanesi, Ortopedi ve Travmatoloji Ana Bilim Dali, Yozgat, Türkiye

Cite as: Kuru T, Olçar HA. Ayak bileği artroskopisi konusunda en çok atıf alan 50 makalenin bibliyometrik analizi. Tepecik Ĕ̌it. ve Arast. Hast. Dergisi. 2020;30(2):133-9.
Holition

\author{
Tolgahan Kuru ๑, Hacı Ali Olçar ${ }^{\circledR}$
}

\section{ABSTRACT}

Objective: Ankle arthroscopy has become an important treatment tool in the management of chronic and posttraumatic ankle problems. In the literature, there are numerous publications on the subject of ankle arthroscopy, including case series, systematic reviews, and prospective cohort studies. The objective of this bibliometric study was to determine the most cited 50 articles on ankle arthroscopy and to analyse characteristics of these studies. Method: The articles published between 1985 and 2019 were screened by two orthopedists via the Web of Science v. 5.11 academic search engine with 'Ankle Arthroscopy' term as of 03/21/2019. Titles, first authors, years of publication of the articles, number of citations, journal of publication, subtype, country of origin and institute of the study were recorded.

Results: The number of total citations was 5378 for all 50 articles. The mean citation number of all articles was found as $107.6 \pm 45.6$ (min-max: 64-240). The articles belonged to 13 different countries of origin. One article was published in 1980s, 13 articles in 1990s, 30 in 2000s, and 6 in 2010s.

Conclusion: The articles on ankle arthroscopy were predominantly case series, and according to our bibliometric analysis we believe that further comparative randomized controlled studies are needed to be conducted on ankle arthroscopy.

Keywords: Ankle arthroscopy, literature, bibliometric study, bibliography, citation number

\section{öz}

Amaç: Ayak bileği artroskopisi, kronik ve posttravmatik ayak bileği problemlerinin yönetiminde önemli bir tedavi aracı haline gelmiştir. Literatürde ayak bileği konusunda olgu serileri, sistematik derlemeler ve prospektif kohort çalışmaları halinde çok sayıda yayın bulunmaktadır. Bu bibliyometrik çalışmanın amacı ayak bileği artroskopisi konusunda en çok atı alan 50 makaleyi belirlemek ve bunların karakteristiklerini analiz etmektir.

Yöntem: Calısmamızda 21/03/2019 tarihi itibarıla Web of Science v. 5.11 akademik arama motorunda "Ankle Arthroscopy" terimi ile 1985 ve 2019 yılları arasında yayınlanan makaleler iki ortopedist tarafından taranmıştır. Makalelerin başlığı, birinci yazarı, yayın yılı, atıf sayısı, yayınlayan dergi, makale alt türü, kaynak ülke ve çalışmanın yapıldığı kurum kaydedilmiştir.

Bulgular: Çalıșmamızda 50 makale için toplam atıf sayısı 5378 olarak saptanmıştır. Tüm makaleler için ortalama atıf sayısı 107,6士45,6'dır (min-maks: 64-240). Bu makaleler 13 farklı kaynak ülkeye aittir. 1980'lerde 1, 1990'larda $13,2000^{\prime}$ lerde 30 ve $2010^{\prime}$ larda 6 makale yayınlanmıştır.

Sonuç: Ayak bileği artroskopisi konusundaki makaleler ağırıklı olarak olgu serileri olup, bibliyometrik analizimize göre ayak bileği artroskopisi konusundan daha fazla karşılaştırmalı ve randomize kontrollü çalışmalar gerektiğini düşünmekteyiz.

Anahtar kelimeler: Ayak bileği artroskopisi, literatür, bibliyometrik çalışma, bibliyografya, atıf sayısı

(C) Telif hakkı TC. Sağlık Bakanlı̆ı izmir Tepecik Eğit. ve Arast. Hastanesi. Logos Tip Yayıncluk tarafindan yayınlanmaktadır.

Bu dergide yayınlanan bütün makaleler Creative Commons Attf-GayriTicari 4.0 Uluslararası Lisansı ile lisanslanmıştr.

(c) Copyright Association of Publication of the T.C. Ministry of Health İmir Tepecik Education and Research Hospital.

This journal published by Logos Medical Publishing.

Licenced by Creative Commons Attribution-NonCommercial 4.0 International (CC BY) 


\section{INTRODUCTION}

Ankle arthroscopy (AA) has become an important treatment tool in the management of chronic and post-traumatic ankle problems. Although anatomy of the ankle is complex, AA is generally known as a "zero problem" procedure. Until 1984, management of the ankle with arthroscopy has been found difficult. Even Burman proposed that the ankle is not suitable for arthroscopy ${ }^{(1)}$. However, significant advancements have been achieved in minimal invasive ankle surgery especially in the last 25 years ${ }^{(2)}$. In parallel to the increasing ankle problems worldwide, both the use of AA is increasing and the technology on this issue is continuously developing.

In the literature, there are numerous studies about AA including case series, systematic reviews, prospective cohort studies, clinical randomized controlled studies, cadaveric studies, and surgical technique notes. These publications contribute to both patient care and development of the techniques in this topic. However, it was thought that identification of the most effective and most important articles among large number of studies will shed light on scientific research on AA.

Creating a citation rank list may be helpful in determination of which articles have the most significant intellectual impact ${ }^{(3)}$. For example, researchers from medical and surgical specialties benefit from the citation analysis in order to determine the most effective articles in their field. Among these, orthopedic surgery ${ }^{(4)}$, plastic surgery ${ }^{(5)}$, general surgery ${ }^{(6)}$, and oncology ${ }^{(7)}$ are the leading specialties that most commonly perform citation rank analysis.

Although citation rank analysis has been made on many topics in the field of orthopedics, no such study was found in the literature about ankle arthroscopy. Therefore, the objective of this bibliometric study was to determine the most cited 50 articles on ankle arthroscopy and to analyze characteristics of these studies.

\section{MATERIAL and METHODS}

The objective of this study was to determine the most cited 50 articles on ankle arthroscopy and to analyze characteristics of these studies. The articles published between 1985 and 2019 were screened by two orthopedists via the ISI Web of Science version 5.11 academic search engine using the term "Ankle Arthroscopy" as of 03/21/2019. The articles in a language other than English, and those did not involve our search term in title or abstract were excluded from the study with the common decision of the two orthopedists. As a result the list of articles were selected among the articles with the highest number of citations to the articles with the lowest number of citations (range: 64-240). The titles and abstracts of the most cited first 50 articles that involved our search term within the text were examined and these articles were included in the study. Titles, first authors, and years of publication of the articles, number of citations, journal of publication, subtype, country of origin and institute of the study were recorded.

Annual citation rate was calculated as: Number of total citations/(2019-Year of Publication). The first 50 articles were divided into decades as follows: 19801989 dated articles were considered as 1980s, 19901999 dated articles as 1990s, 2000-2009 dated articles as 2000s, and 2010-2019 dated articles as 2010s.

\section{Statistical Analysis:}

Data of the study were analyzed using SPSS 20.0 statistical package software. The results were expressed as numbers, percentages, mean, standard deviation, median, minimum and maximum.

\section{RESULTS}

\section{Fifty Most cited Articles:}

The most cited 50 articles published between 1985 and 2019 were screened with 'Ankle Arthroscopy' via the ISI Web of Science version 5.11 academic 
search engine by the two orthopedists, and evaluated with their titles and abstracts.

The total number of citations was found as 5378 for all 50 articles. The mean citation number of all articles was found as 107.6 \pm 45.6 (min-max: 64-240). Citation number of 10 articles was higher than the other 150 articles. The most cited article was titled as 'A 2-portal endoscopic approach for diagnosis and treatment of posterior ankle pathology' by van Dijk $\mathrm{CN}$ published in 'The journal of Arthroscopic and Related Surgery' in 2000 (total citations: 240). The least cited article was titled as 'The Value of Subtalar Arthroscopy in the Management of Intraarticular Calcaneus Fractures' by Rammelt S published in the journal of 'Foot Ankle International' in 2002 (total citations: 64).

When the mean citation numbers were examined by decades; the mean number of citations was found as 99 in 1980 s, $97.38 \pm 26.09$ in 1990 s, $109.5 \pm 45.6$ in 2000s and $122.33 \pm 41.8$ in 2010s (Figure 1).

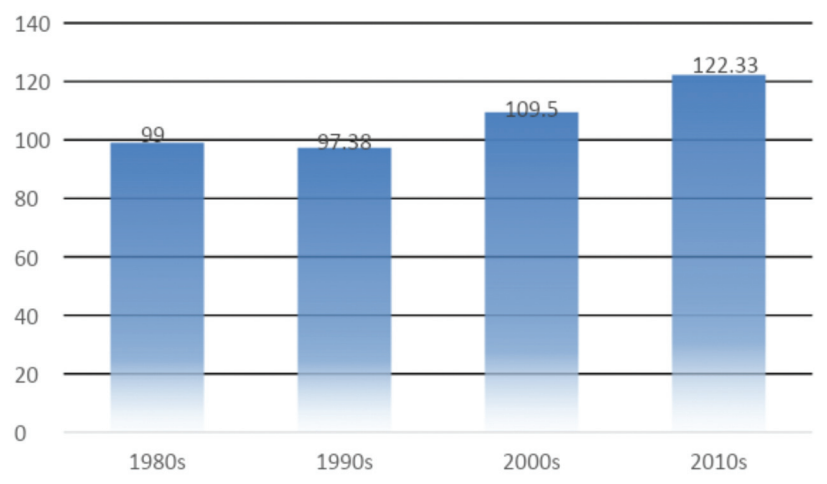

Figure 1. Mean citation number by decades.

Countries of Origin: The articles were published in 13 different countries (Table 1). The articles were most commonly published in the USA $(n=18)$ followed by Netherlands $(n=7)$, Canada $(n=4)$ and Italy $(n=5)$. Percentage distribution of the countries of origin is given in Figure 2. Of the most commonly cited articles, $36 \%$ were published in the USA alone.
Table 1. Countries of origin.

\begin{tabular}{lc}
\hline Country & $\mathbf{n}(\%)$ \\
\hline United States of America & $18(36)$ \\
Netherlands & $7(14)$ \\
Canada & $4(8)$ \\
Italy & $4(8)$ \\
Germany & $3(6)$ \\
Japan & $3(6)$ \\
Hungary & $3(6)$ \\
South Korea & $2(4)$ \\
Switzerland & $2(4)$ \\
Brazil & $1(2)$ \\
China & $1(2)$ \\
England & $1(2)$ \\
Portugal & $1(2)$ \\
& \\
\hline
\end{tabular}

n: Number, \%: Percentage

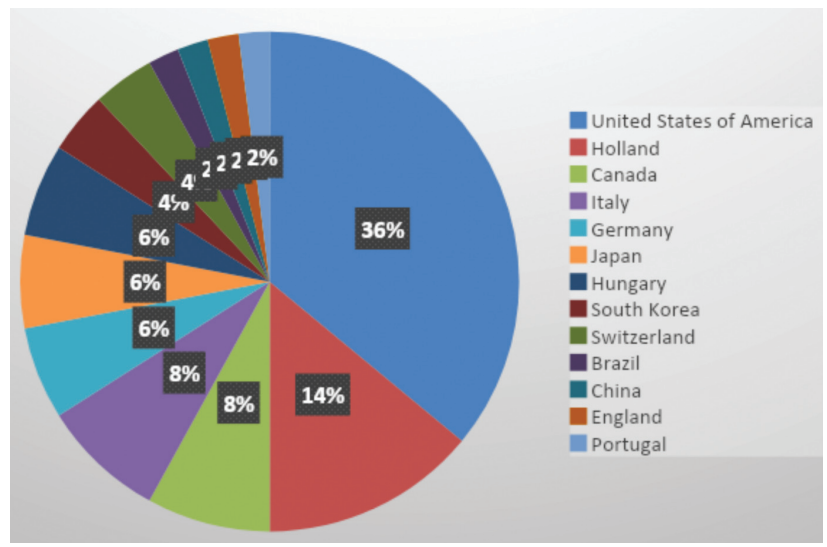

Figure 2. Percentage distribution of the countries of origin.

Top Publication Journals: The most commonly cited articles on ankle arthroscopy were published in 11 journals. The journals with the highest number of articles cited on this subject were 'The Journal of Arthroscopic and Related Surgery' ( $n=12$ ), 'American Journal of Sports Medicine' $(n=10)$ and 'Foot Ankle International' ( $n=9$ ) (Table 2). The first three journals contained $62 \%$ of the most cited 50 articles.

Table 2. Top Publication journals.

\begin{tabular}{lc}
\hline Journal & $\mathbf{n}(\%)$ \\
\hline The Journal of Arthroscopic and Related Surgery & $12(24)$ \\
American Journal of Sports Medicine & $10(20)$ \\
Foot Ankle International & $9(18)$ \\
Journal of Bone and Joint Surgery American Volume & $5(10)$ \\
Journal of Bone and Joint Surgery British Volume & $5(10)$
\end{tabular}

n: Number, \%: Percentage, *: Percentages were evaluated over 50 articles. 
Decades of Publication: The number of the articles analyzed according to the decades of their publication; 1980s $(n=1)$, 1990s ( $n=13), 2000 s(n=30)$, and 2010s ( $n=6)$ (Figure 3). The oldest article was published by Martin DF in 'American Journal of Sports Medicine' in 1989, and titled 'Operative Ankle Arthroscopy. Long-term Follow up. The last article was published by Nickisch F in 'Journal of Bone and Joint Surgery American Volume' in 2012, and titled 'Postoperative Complications of Posterior Ankle and Hindfoot Arthroscopy'. The decade with most frequently cited publications was 2000s with 30 articles (60\%).

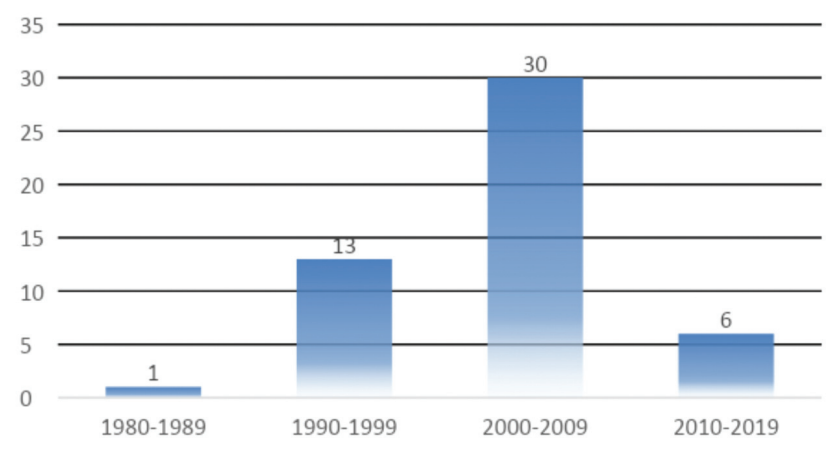

Figure 3. Number of publications by decades.

Top Authors: There were 34 first authors in the most cited 50 articles and the authors with highest number of articles were Ferkel RD ( $n=6)$, van Dijk CN $(n=5)$, Giannini S ( $n=3)$, and Hangody L ( $=3$ ) (Table 3).

Table 3. Top authors.

\begin{tabular}{lc}
\hline Author & $\mathbf{n}(\%)$ \\
\hline Ferkel RD & $6(12)$ \\
van Dijk CN & $5(10)$ \\
Giannini S & $3(6)$ \\
Hangody L & $3(6)$ \\
\hline
\end{tabular}

$n:$ Number, \%: Percentage, *: The percentages were evaluated over total 50 articles

Top Institutions of Publication: Of the total 50 articles, 49 were published by 31 different institutions. One article had no institution of publication. The institutions with the highest number of publications were 'Academic Medical Center' ( $n=5)$ and 'Southern California Orthopedic Institute' ( $n=5)$ (Table 4).
Topics: Subtypes of the articles evaluated were as follows; 25 (50\%) were case series, 14 (28\%) systematic reviews, 6 (12\%) prospective cohort studies, 2 (4\%) clinical randomized controlled trials, 2 (4\%) cadaveric studies, and $1(2 \%)$ surgical technical note (Table 5) (Figure 4).

Table 4. Top institutions of publication.

\begin{tabular}{lc}
\hline Institutions & $\mathbf{n}(\%)$ \\
\hline Academic Medical Center & $5(10)$ \\
Southern California Orthopedic Institute & $5(10)$ \\
University of Bologna & $3(6)$ \\
Uzsoki Hospital & $3(6)$ \\
\hline
\end{tabular}

n: Number, \%: Percentage, *: Percentages were evaluated over 50 articles

Table 5. Topics.

\begin{tabular}{lc}
\hline Article subtype & $\mathbf{n}(\%)$ \\
\hline Case series & $25(50)$ \\
Systematic review & $14(28)$ \\
Prospective cohort study & $6(12)$ \\
Clinical randomised controlled trial & $2(4)$ \\
Cadaveric study & $2(4)$ \\
Surgical technical note & $1(2)$
\end{tabular}

n: Number, \%: Percentage, *: Percentages were evaluated over 50 articles

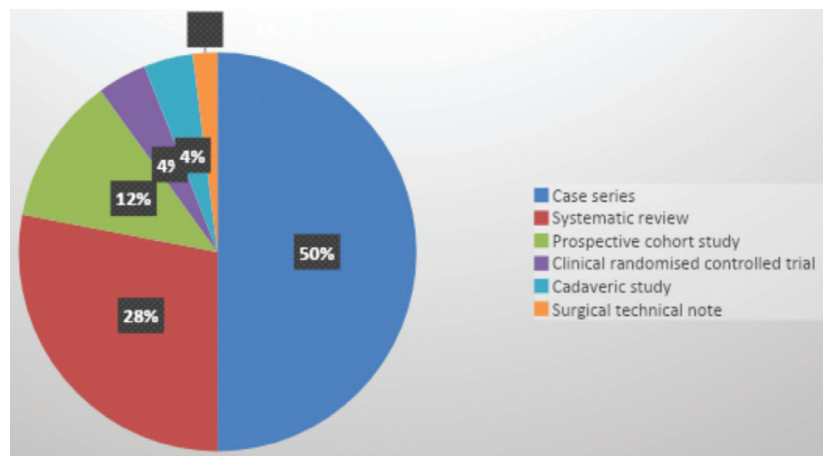

Figure 4. Percentage distribution of topics.

\section{DISCUSSION}

The ankle has a complex anatomy, and preoperative insight of the mechanism of ankle stability and resulting disability is of paramount importance for the management of pathologies in this region. Within this context, arthroscopy has a critical role in postoperative determination of post-traumatic or chronic ankle pathologies. Preoperative ankle arthroscopy provides 
significant information on ankle instability and different intraarticular pathological conditions ${ }^{(8)}$.

In this bibliometric study on ankle arthroscopy, the most cited articles between 1985 and 2019 were analyzed. As a result of this analysis, it was found that, ankle arthroscopy has been widely studied in the literature.

The most cited first article on AA was 'A 2-portal endoscopic approach for diagnosis and treatment of posterior ankle pathology' by van Dijk CN with 240 citations. In this article, a 2-portal endoscopic approach was described in the diagnosis and treatment of posterior ankle pathology. It was emphasized that it is possible to view and treat various posterior ankle problems with this approach. It was reported that, not only posterior ankle joint, but also periarticular pathologies such as calcifications and scar tissue can be detected and treated with this approach ${ }^{(9)}$.

The most cited second article was 'Treatment of osteochondral lesions of the talus: a systematic review' which was published by Maartje Zengerink in 2010, with 229 total citations. At the same time this article has the highest annual citations (25.4) among the first 50 articles. This article was a systematic review and involved the treatment of osteochondral lesions of talus. It was stated in the article that, most publications on the treatment of osteochondral lesions of talus involved arthroscopic excision, curettage, and bone marrow stimulation ${ }^{(10)}$.

The most cited third article was 'Arthroscopic findings in patients with chronic ankle instability' by Hintermann B in 2002. Total citations of the This article received a total of 184 citations. The article discusses arthroscopic findings in patients with chronic ankle instability. In the study, arthroscopic examination findings of 148 patients with chronic ankle instability which lasted 6 months or more were compared with clinical diagnosis ${ }^{(8)}$.
Among the first 50 most cited articles, the oldest article was published in 1989 by Martin DF. The article included long-term follow up results of operative ankle arthroscopy. The article received a total number of 99 citations with a mean annual citation number of 3.3. It was reported in the conclusion of the study that, ankle arthroscopy has significant risk of complication, but good results can be obtained with proper indications, knowledge of anatomical landmarks and a meticulous technique ${ }^{(11)}$.

The most recent article was published by Nickisch $\mathrm{F}$ in 2012 with 67 total citations. The article examined postoperative complications of ankle and hindfoot arthroscopy. According to the article, rate of major postoperative complications is relatively lower with arthroscopic procedure ${ }^{(12)}$.

In the literature, the mean citation number varies among the similar bibliographic studies. In a similar study, Ankomah et al. ${ }^{(13)}$ analyzed the most cited 50 articles on thoracolumbar fractures. The mean number of 128.64 citations was reported. Iftikhar et al. (14) published a bibliometric analysis of the most cited 30 articles on gestational diabetes mellitus between 1946-2019. The mean number of 829 citations was reported. In a bibliometric analysis of the most cited 100 articles on rheumatoid arthritis Yin et al. (15) reported the mean number of 1102 citations. In our study, the mean citation number of all articles was found as 107.6. There are two main reasons for differences between the studies. First is the difference between topics of the studies, and the second is the time period when the articles were examined. For example, time period was 73 years in the bibliographic analysis by Iftikhar et al. ${ }^{(14)}$, while this duration was 34 years in our study.

The average number of citations by decades was as follows; 99 in 1980, 97.38 in 1990s, 109.5 in 2000s and 122.33 in 2010s. As is seen there is a linear relationship between the citation numbers and decades of publications. We attributed this increase both to 
advancements in arthroscopic technology, and to the increased use of internet especially as of 1990s.

The highest number of publications belonged to the period of 2000-2009. Six articles were published in 2010s. This might be resulted from that development of the arthroscopic technology has taken place in the 2000s. Articles published in 2010 predominantly included long-term outcomes of ankle arthroscopy.

The articles were from 13 different countries of publication received citations. The most cited articles came from the USA, Netherlands, Canada and Italy in order of decreasing frequency. The USA was the country of publication in $36 \%$ of all articles cited. In parallel to the top countries of publication, the most cited articles were published by Academic Medical Center' from the Netherlands, and 'Southern California Orthopedic Institute' from the USA.

Subtypes of the articles evaluated were as follows; 25 were case series, 10 systematic reviews, 6 prospective cohort studies, 2 clinical randomized controlled trials, 2 cadaveric studies, and 1 surgical technical note. It is remarkable that, number of clinical randomized controlled trials was limited in number.

Data analysis of this study was objective and comprehensive, although there were some limitations. Firstly, only articles written in English language were included in the analysis, The second limitation was related to years of publications. For example, we can not expect citation number of a recently published high-quality article on ankle arthroscopy will be greater than an article published a decade ago or earlier.

\section{CONCLUSION}

This study was conducted to evaluate the most cited 50 articles about ankle arthroscopy. Our bibliographic analysis provided both qualitative and quantitative analyses of the most cited articles on ankle art- hroscopy. Our study is the first in the literature to evaluate the most cited articles about ankle arthroscopy, which has an important place in the management of ankle pathologies. Our results have indicated that the articles on this issue were predominantly case series, and according to our bibliometric analysis we believe that conduction of further comparative randomized controlled studie is needed on ankle arthroscopy.

\section{Acknowledgement: None}

Ethics Committee Approval: Since our study did not include human or animal subjects and our study was a bibliometric analysis, Ethics Committee Approval was not required.

\section{Conflict of Interest: None.}

Funding: None.

Informed Consent: As it was a internet database study,informed consent was not obtained.

\section{REFERENCES}

1. Burman MS. Arthroscopy or the direct visualization of joints: an experimental cadaver study. 1931. Clin Orthop Relat Res. 2001;390:5-9. [CrossRef]

2. Maartje Zengerink and C. Niek van Dijk. Complications in ankle arthroscopy. Knee Surg Sports Traumatol Arthrosc. 2012;20(8):1420-31. [CrossRef]

3. Murray MR, Wang T, Schroeder GD, et al. The 100 most cited spine articles. Eur Spine J. 2012;21:2059-69. [CrossRef]

4. Kelly JC, Glynn RW, O'Briain DE, et al. The 100 classic papers of orthopaedic surgery: a bibliometric analysis. J Bone Joint Surg Br. 2010;92:1338-43. [CrossRef]

5. Loonen MP, Hage JJ and Kon M. Plastic Surgery Classics: characteristics of 50 topcited articles in four Plastic Surgery Journals since 1946. Plast Reconstr Surg. 2008;121:320e-7e. [CrossRef]

6. Paladugu R, Schein M, Gardezi S, et al. One hundred citation classics in general surgical journals. World J Surg. 2002;26:1099-1105. [CrossRef]

7. Tas F. An analysis of the most-cited research papers on oncology: which journals have they been published in? Tumour Biol. 2014;35:4645-9. [CrossRef]

8. Hintermann B, Boss A, Schäfer D. Arthroscopic findings in patients with chronic ankle instability. Am J Sports Med. 2002;30(3):402-9. [CrossRef]

9. van Dijk CN1, Scholten PE, Krips R. A 2-portal endoscopic approach for diagnosis and treatment of posterior ankle pathology. Arthroscopy. 2000;16(8):871-6. [CrossRef]

10. Zengerink M1, Struijs PA, Tol JL, van Dijk CN. Treatment of osteochondral lesions of the talus: a systematic review. Knee Surg Sports Traumatol Arthrosc. 2010;18(2):238-46. 
[CrossRef]

11. Martin DF, Baker CL, Curl WW, Andrews JR, Robie DB, Haas AF. Operative ankle arthroscopy. Long-term follow up. Am J Sports Med. 1989;17(1):16-23. [CrossRef]

12. Nickisch F, Barg A, Saltzman CL, Beals TC, Bonasia DE et al. Postoperative complications of posterior ankle and hindfoot arthroscopy. J Bone Joint Surg Am. 2012;94(5):439-46. [CrossRef]

13. Ankomah F, Ikpeze T, Mesfin A. The Top 50 Most-Cited
Articles on Thoracolumbar Fractures. World Neurosurg. 2018;118:e699-e706. [CrossRef]

14. Iftikhar PM, Ali F, Faisaluddin M, Khayyat A, De Gouvia De Sa M. et al. A Bibliometric Analysis of the Top 30 Most-cited Articles in Gestational Diabetes Mellitus Literature (19462019). Cureus. 2019;11(2):e4131. [CrossRef]

15. Yin X, Cheng F, Wang X, Mu J, Ma C et al. Top 100 cited articles on rheumatoid arthritis: A bibliometric analysis. Medicine (Baltimore). 2019;98(8):e14523. [CrossRef] 